\title{
A conversation with George Bowering
}

Eloína Santos ${ }^{1}$

Submetido em 22 de julho e aprovado em 24 de julho de 2017.

I first landed in Vancouver in 1993 with a grant from the Canadian Government and the aim of prospecting Canadian authors to teach at Universidade Federal do Rio Grande do Sul, in the city of Porto Alegre, at the south of Brazil. I chose Simon Fraser University to do my research in an attempt to contact George Bowering, said, at the time, to be a foremost postmodern writer.

Unable to meet him at the university, the department was nice enough to suggest I phone him - which was really scary, but I did. And he offered to come and see me, since he lived far from the city. And we met, of all places, at the cafeteria of the Vancouver Y, where I was staying. In walked this very tall and thin man, with a large smile and a book in his hand. Almost a continent apart, after about two hours of chatting we discovered two dear authors in common, novelist William Eastlake, the subject of my doctoral dissertation, and poet Robert Creeley, who was writer in residence at SUNY, Buffalo and was a member of my Dissertation Committee (1988), since he and Eastlake had been friends. The novel George gave me was a hard cover copy of Caprice (1987), my favorite work of his to this day, the second novel of his Western trilogy. A novel that has a close relation to some of the subjects I have taught and written about - the post regional Western and the Native American novel. We sat for another exchange about Westerns, Eastlake and Western Canada at a very noisy sports bar, where I learned about his passion for baseball, also present in his writing.

In 1995 I went back to Vancouver and George and I sat at the outdoor café of the recently opened Public Library in downtown Vancouver, housed inside an unconventional building designed by Moshe Safdie, today the third largest library in Canada. There we chatted until I was freezing and George almost late for a dissertation committee. From then on we keep in touch on and off, made easier now that I can follow him on Facebook. 
It is almost impossible for readers or critics to keep track of George's extensive writing activity and there are very good interviews with him online, so the reason for this brief exchange is especially directed to bringing Bowering's work, his Western Canada, his work on Canadian writers and his unbreakable sense of humor closer to Brazilian and Latin American readers of Interfaces.

Eloína Santos: I have been looking for material about your visit to Rio. Do you remember the year? Did you come for the launching of any translation of one of your books? The only book of yours available to us at Brazil Amazon is Caprice, to my great satisfaction, but in English.

Gorge Bowering: The year I was supposed to come to Brazil was 1999, I think, maybe 1998. You had arranged that I spend a week in each of four cities, including Porto Alegre, talking with writers, giving talks and readings, etc. But then my wife Angela's cancer got really bad, and I cancelled the trip to be with her. She died in September of 1999. The closest I have got to Brazil (and Rio), was when Jean and I took a cruise ship around the Horn and up to Valparaiso. The cruise began at Rio, but we got on board at Buenos Aires.

ES: Too bad you did not board the cruise in Rio. Somehow it's got some aspects I find similar to Vancouver, maybe just the mountains near the water, a forest within the city... But we can talk about themes that have to do with this journal - Canada/Brazil "interfaces" - as well as your writing focused on Canadian themes, like Burning Water, or the Canadian West and the city of Vancouver.

George Bowering: When I was a young guy, first looking at fiction by Canadian writers, such as Morley Callaghan and Hugh MacLennan, I saw that these guys set their stories in the USA, or in a city that was not identified, with ordinary street names, so readers could assume it was in New York or Buffalo. This was partly due to the fact that Canadians had to get US publishers or forget it. Well, I liked reading US novels that really got the experience of living in Chicago (James T. Farrell) or Los Angeles (Richard Prather). I had learned that when you are writing poetry it is a really good idea to attend to 
the details of the space you live in. I decided to apply that to my fiction. Mordecai Richler did this very well with Montreal. I started with the streets of Vancouver and then said to heck with it, I am going to write the brown grass and purple hills and green river of the land I was brought up in. Get that right and you have a chance of telling what Hemingway called a true story about people's lives.

ES: In the "Author's preface" to Imaginary Hand, (1988) you state that "works I look at tend to show a history full of holes but moving westward". As a young man you were a photographer for the Canadian Air force. Was that helpful in giving your writing about the western shore of Canada a more encompassing view of the "brown grass and purple hills and green river" of the land you were brought up in, so that "a reader may [also] notice a kind of geography" [in your critical voice]? Caprice and Burning Water give that impression. But most of your writing is known to be very funny and rather cruel satire. How do you par that with the affectionate view of the Canadian West that is present in your work?

GB: That is a good and difficult question. That mixture of feelings (cruel satire and love) is there and has always been there in my response to the land I grew up in. When I see that dry wild grass, the cactuses, the sand and rock of my landscape, I feel my poor old heart softening, and tears are actually around my eyeballs. You will see this certainly in the landscape I spend so many words on in the novel Shoot! (1994; 2008), and you will see my disregard for some of the stupid and malignant people who spend their lives taking for granted the landscape I love. It happens that the landscape I grew up with is also there in Hollywood Westerns. So I loved them, and read a lot of cowboy novels. The town I grew up in votes right-wing and pretty well lives without art and culture. But when I see some quail running across the powdery road in front of me, I drop everything and watch.

ES: Do you believe humor and satire make life more bearable or more distant, more believable or more human?

GB: I don't know why, but I have looked at the world and all its parts through a 
lens of humour, not just satire, but slapstick, and everything in between.

My best friends and my family have died, but I still see the world as funny. My very favourite comedian is Samuel Beckett.

ES: Shoot! is peopled by a group of "breeds", or mixed bloods (a Vizenor term) Scottish and Salish. It is a true western story and also a satire of "classic" westerns. How much can humor and satire do for people who are caught in the middle of the"hibridity question"?

GB: I have noted somewhere that whereas the Great Modernists were a dead serious lot, their only kind of humor was some irony, as in T.S. Eliot. But the postmodernists, however you describe them, have the comic vision central to their work, and they use every kind of humor, including slapstick. Vonnegut even used the word for a novel's title. They (we) descend from Beckett, the greatest humorist of the 20th Century, I think; Robert Kroetsch is our great post-modernist, and humourist.

ES: Has academic writing, which seems to me a lot tamer than your fiction, but as wide ranging in themes, helped you think out the mechanics of your writing? Sometimes you seem to cite poems that could define your own writing - as Ondaatje's, "The Gate in His Head", from Rat Jelly - a great title! (Imaginary hand, p. 164)

My mind is pouring chaos

in nets onto the page

And that is all his writing should be then.

The beautiful formed things caught at the wrong moment so they are shapeless, awkward, moving to the clear.

Is that an early definition of décriture that then grows into satire and wild humor?

GB: That quotation does tell us about Mike more than it does about me. But it also tells you what Mike likes in my fiction and Kroetsch's. As to my essays: I was pleased when bpNichol said my essays were like fiction and my fiction was like essays. I certainly see a continuum. A lot of my favourite writers offer me really good fiction and really good 
essays. Like Robert Kroetsch, John Berger, Jerome Charyn, Guy Davenport.

ES: Although you have written about several great women writers, I am interested in your views of some writers from the West, as Margaret Laurence and Marian Engel, whose Bear (1976) I find a fantastic self-discovery adventure.

GB: I published, regarding Laurence, the first essay on A Jest of God (1966). Later, when an anthology of essays about her work was being put together, she told the editors to add my essay because apparently I was the first critic to say the right things about her efforts to do something interesting with the writing rather than just to make a convincing replication of prairie life. As to Marian Engel - I prefer the writing of her exhusband Howard Engel, author of the Benny Cooperman series. I never really saw her writing as interesting. As to Bear - I agreed with a lot of people who made jokes about it. I could just be missing something, I don't know. She's not a western writer, as far as I know. I associate her with Ontario.

ES: Following that up there is also Lee Maracle. What First Nations writers do you read? I am very fond of First Nations' satires of westerns, as Thomas King's.

GB: Lee Maracle I have just casually read a little of. I have read a lot of King. I liked his comic radio series called "The Dead Dog Cafe". He photographed me for a book cover.

First Nations writers are all the (manufactured) rage in Canadian book-talk now. I was the first person to publish an essay on Mourning Dove, who wrote the first ever novel by an indigenous North American woman. She lived in the Okanagan Valley, as I did, and died about the time I was born.

Returning to the subject of western Canadian women writers, I believe that Sheila Watson's The Double Hook (1959) is our greatest novel ever. I have done a lot of work on her.

ES: Yes. Watson. I read her. And agree with you that it is not enough to live in an area to belong to it artistically. Unfortunately, I never read Engel's husband. 
GB: The other great woman writer from the Canadian west (Vancouver) is/was Ethel Wilson. No one could write sentences as well as she could. I wrote the afterword to a paperback edition of her great novel Swamp Angel.

ES: 20 Swamp Angel (1990, first published 1954) and Mrs. Golightly and other stories (1990, first published in1961), both bought in Toronto in 1995. Last century! The good ones never age.

Laurence's Jest of God (1966) was adapted to a film called Rachel, Rachel (1968) directed by Paul Newman and then reprinted with the usual cover picturing the actors. Apparently movies have the power of making authors of the books they are based on famous all over the world. In "A great northward darkness" you say that Canadians write (wrote?) books against obscurity $[\ldots]$ in two languages brought from Europe, and wish they would be read or turned into movies in the United States" (Imaginary hand, p. 1).

Your novels would render great films, and I am thinking about Caprice specifically, but the same can be said about the other books of the historical trilogy. Have any of your books become a movie? Have you been approached about it?

GB: Caprice was optioned four times, and came really close to being done down there in Hollywood, and then just didn't. Other books were optioned too. Helped me buy a car, etc. Two of my stories were made into short films. ${ }^{2}$ But no big deals.

ES: I guess one of the reasons for the interview is getting justified. Not many Brazilians are aware of Canadian literature, except for academics that teach and study it, mostly in their original languages. Canada is known for its natural beauty, great tourism or the country that gives the most grants to foreign students, receives the most immigrants, all greater assets now that we are all avoiding Trump's Great America.

Translation here (everywhere?) is quite idiosyncratic and seems to have no policy other than publisher's choices of writers that have become very well known. Ondaatje`s The English Patient (1992) was translated here after the movie (Companhia das Letras, 2007). The only other book of his in translation here is In the Skin of a Lion (1987), Na pele de um leão (1998). 
GB: The star system infests everything. In Canada itself, I know some novelists who have been with the same big-deal publishers for several books, who have been told by their publisher that they will not publish their new manuscript because it does not look as if it will win any prizes. The newspapers that used to publish a lot of reviews now consider their job done, as far as books are concerned, if they run a best-seller list and news about prizes. A lot of newspapers have died, and most of the rest are more likely to review comic-book movies and video games.

ES: It is so easy now to get information online about any books and authors, that book reviews have disappeared from newspapers. Our local newspaper had a nice Sunday supplement entitled "Cultura" with book, film and theatre reviews. Its current version is . $d o c$, subtitled "reporting in focus". It has stories about medical malpractice, famous sports figures, the sad state of our museums and interviews about books worth reading, most of them not literature.

GB: As to translations abroad - some countries do a lot of Canadian books, while others do only big stars like Atwood and Ondaatje (this has become a kind of joke here). China, which used to pirate our books, now actually observes copyright.

ES: So we have good reason to examine that exchange, or lack of. Do you know any Brazilian writers in translation?

GB: I have read books by Machado de Assis (when I was a youngster), Clarice Lispector (some I liked, others I didn't so much), Jorge Amado (he was popular around 1975). Paulo Coelho is readily available, but I haven't read him. I am not saying that you find these writers' books easily. But you can get them.

My favourite Brazilian writer is Moacyr Scliar, but my friends haven't read him. His books are published by an obscure publisher, whereas some like Lispector is published by New Directions. As to poetry - I have always read Latin-American poetry written in Spanish, and when I was young I often published in magazines in Mexico, Venezuela and Argentina, especially. But I don't know anything about Brazilian poetry, nor do I read Brazilian. 
ES: Machado is always a good read and the translations are good. Please do not ever bother to read Paulo Coelho. I never understood how he ever got to be such a hit in world book fairs while we have so many great writers being translated and going to fairs, like Scliar himself. I have read almost all of Scliar's novels. He left us too early, but we are having a yearlong celebration for his $80^{\text {th }}$ birthday.

Moving on, I've been curious about how you became the first Parliament Poet Laureate.

GB: Well, there is a Senator, Gerry someone, who thought it was a shame that we didn't have a Parliamentary Poet Laureate, so he got a bill passed in favor of one, in the Senate, and eventually it was passed in the House of Commons. Usually bills go the other way. The news came out, and on a whim I wrote a bragging letter, and a lot of people were consulted, and I got the job. So at least they started with a real poet. Two years. Then they had a French Canadian woman who was an idiot, and did a TV show for children. Don't know how she got the job. Most of the PLs have been a waste of time, except for Fred Wah, who did a bangup job till two years ago.

ES: Never a great fan of US America, but at the same time a great admirer of its writers, how do you see the Trump administration in relation to Canada?

GB: Trump and the US Americans who chose him are unbelievably sad, funny, unbelievable. He has the vocabulary and personality of a 10-year-old boy. If we had been shown a preview of him 50 years ago we would have refused to believe that the job would have sunk so low. There are 458 people in Canada who are in favour of Trump. I met one in the hospital. She liked Trump and ice hockey. She did not like black people or gay people. I did not hang around to find out who else she didn't like.

ES: You have written in every genre, poetry, satiric westerns, criticism, fiction, plays. Do you choose them or do they choose you somehow?

GB: Oh, I choose them. Then they go to work on me. 
ES: Does it come to you as easily as it seems - from the great amount of consistently great work you have been publishing at the same pace, for many decades?

GB: There is a short story that I started in March or April. I am beginning to see what it is about. The day before yesterday I changed the main character's last name. That ought to answer your question.

ES: I want to wrap this exchange up by going back to Brazil/Canada "interfaces". Despite speaking four official languages (and another hundred others we mostly ignore), most countries in the American continent having similar stories of colonization, native genocide and slavery which have rendered great bodies of literature that have innovated European inherited genres, why do you think we still privilege American-European cultural exchanges over Inter-American dialogues? Is there anything we can do to steer this paradigm in another direction? It was with this spirit that Canadian/Brazilian studies begun, but even so I have a feeling we end up following a French/French and an English/ English interchange and it is not only due to the translation obstacle.

GB: I am baffled as to why we have more exchanges with European and British Commonwealth literatures and other cultural things. It pisses me off that our newspapers are not at all interested in what happens in South America. Same with TV news. In Canada, we don't hear anything about Quebec lit/culture, either.

ES: I will never be able to thank you enough for this exchange, George, especially because it was carried out during the month of June, while you recovered from a broken hip and I took advantage of the fact that you were unable to write full time and generous enough to agree to answer my questions. It is good to know that you are recovering well and that you have gone back to work at proofreading works soon to be published. 


\section{Notes}

1 Professora aposentada da Universidade Federal do Rio Grande do Sul; Editora Assistente da Revista Interfaces Brasil/Canadá, eloinaprati@gmail.com

2 https://www.youtube.com/watch?v=zn8zDG-D69o (2013), "a little black strap". Published in the chapbook a little black strap by Unarmed, St. Paul, 2009. https://vimeo.com/29456398 (2011), "Standing on Richards Elvis". Published in Standing on Richards, Viking, 2004.

3 Professora Titular do do Programa de Pós-Graduação em Estudos Literários da Universidade Federal Fluminense.

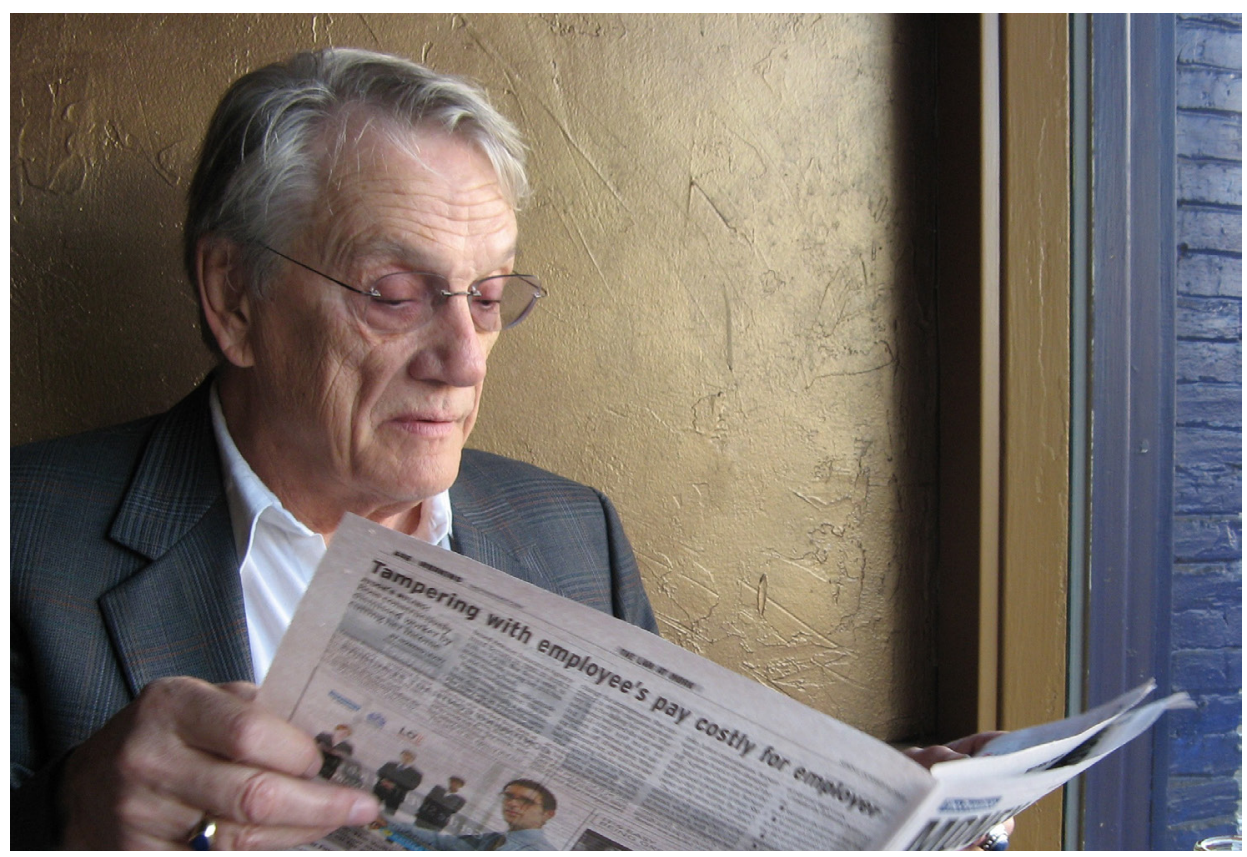

George Bowering was born in Penticton, British Columbia in 1935 and grew up in the nearby town of Oliver. He is one of Canada's most prolific writers, with over one hundred books to his credit, not including more than thirty chapbooks. A poet, novelist, essayist, critic, professor, historian, and editor, he is also an enthusiastic supporter of emerging writers. His writing has been translated into French, Spanish, Italian, German, Chinese, and Romanian. He has twice won the Governor General's Literary Award - for poetry (1969) and for fiction (1980) -, the bpNichol Chapbook Award for Poetry (1991 and 1992), the Canadian Author's Association Award for Poetry (1993), holds Honorary Doctorates from the University of British Columbia (1994) and University of Western Ontario (2003), was the recipient of the Order of Canada (2003) and the Order of British Columbia (2004), and was appointed the first Parliamentary Poet Laureate (2202-2004). He also received the Lieutenant Governor's Award for Literary Excellence (2005) and The Pandora Collective Distinctive Body of Work Award (2011). 
His writing is quite experimental and his sharp witted, skeptical take on human nature and politics is definitely provocative in his discussing of what might be original about B. C. and the Canadian poet within a Eurocentric culture. A representative sample of his poetry can be found in Rocky Mountain Foot (1969), The Ganges of Kosmos (1969), Autobiology (1972), Selected Poems: Particular Accidents (1980), West Window (1982), The Kerrsidale Elegies (1984), Delayed Mercy and other poems (1987), Vermeer's Light: Poems 1996-2006 (2006) and The World, I guess (2015). Like the work of the U.S. poets he admires - William Carlos Williams and Robert Creeley - Bowering's poems, even at their most extended and philosophical, use vernacular, everyday language, and focus on immediate aspects of everyday life. From his fiction, A Short Sad Book (1977) and the historical trilogy about British Columbia, Burning Water (1980), Caprice (1988) and Shoot! (1994) stand out. He has also published seven collections of critical essays, five memoirs, three books of historical nonfiction and six plays. 